\title{
Using SAPR Model for Solution of Social Poverty Problem Due to Covid-19 in Makassar City
}

\author{
Suwardi Annas ${ }^{1}$, Syafruddin Side $^{2}$, Andi Muhammad Ridho Yusuf Sainon Andi Pandjajangi ${ }^{3}$, Nurul \\ Fadilah Syahrul $^{4}$, Luthfiah Arradiah ${ }^{5}$ \\ ${ }^{1,}$ Statistics Department, Universitas Negeri Makassar, Indonesia \\ ${ }^{2,3,4}$ Mathematics Department, Universitas Negeri Makassar, Indonesia \\ ${ }^{5}$ Sociology department, Universitas Negeri Makassar, Indonesia
}

\begin{tabular}{l}
\hline \hline Article Info \\
\hline Article history: \\
Received : $08-16-2021$ \\
Revised : 10-15-2021 \\
Accepted : $10-18-2021$
\end{tabular}

\section{Keywords:}

Modeling Mathematics; Social Poverty Problem; SAPR Model; COVID-19.

\section{ABSTRACT}

This study aims to build an SAPR model on the problem of poverty, analyze the model, predict the number of poverty rates in the city of Makassar, and determine the parameters that affect the decrease in the number of poverty rates due to Covid-19 in the city of Makassar. This research is quantitative. The population of this study is the number of people in Makassar City who are affected by the spread of COVID-19, while the sample of this study is 400 people. The research stages are: Building the SAPR model on the level of social poverty, determining and analyzing the stability of the equilibrium point, determining the value of the basic reproduction number (R0), conducting model simulations using Maple. The results shown that the mathematical model of SAPR which is a non-linear system of differential equations can be a reference model for the problem of poverty; The results also shown that the analysis of the social poverty level of the population finds two equilibrium points, namely the free equilibrium point for the poor and the poor; the stability of the equilibrium point is free-poor and poor; The basic reproduction number $\mathrm{R} 0=0.426$ indicates that the poverty level of the social population can be controlled even though it has increased. Based on the model simulation, it was found that the parameter in the form of business funding assistance from the government could reduce the poverty rate due to the Covid-19 pandemic in Makassar city.

Accredited by Kemenristekdikti, Decree No: 200/M/KPT/2020 DOI: https://doi.org/10.30812/varian.v5i1.1399

This is an open access article under the CC BY-SA license.

Corresponding Author:

Syafruddin Side,

Department of Mathematics, Universitas Negeri Makassar.

Email: syafruddin@unm.ac.id

\section{A. INTRODUCTION}

Makassar as the largest metropolitan city in eastern Indonesia with the largest population in South Sulawesi. Based on data from the Central Statistics Agency, the population of Makassar city in 2016 was 1,469,601 people, and in 2017 it increased to $1,489,011$ people. The data shows that population growth in Makassar city has increased by $1.32 \%$. This increase in population is one of the causes of the swelling of the workforce in the city of Makassar because of the large number of people who are looking for work (Sauddin et al., 2019).

A new virus that can cause an increase in pneumonia first appeared in Wuhan, China, in early December 2019 (Abdy et al., 2021). According to WHO monitoring, until February 2021 Coronavirus Disease-19 (Covid-19) is the newest type of corona virus found in the city of Wuhan, China in December 2019 (Torrealba-Rodriguez et al., 2020). The number of cases of infection with the corona virus that causes Covid-19 continues to increase in various parts of the world. The rate of increase, both for the number of cases of infection, death and cure, varies in each country. Each country also has its own policy to curb the spread of the virus that occurs in its territory. According to data compiled by Johns Hopkins University, as of March 23, 2020, the total number of 
Covid-19 cases worldwide has reached 331,273 cases, with 14,450 deaths, and 97,847 patients declared cured (Annas et al., 2020). Previously, there were several types of corona viruses, including the Severe Acute Respiratory Syndrome Coronavirus (SARS-CoV) in 2002 and the Middle East Respiratory Syndrome Coronavirus (MERS-CoV) in 2012 (Shereen et al., 2020). Confirmed patients have reached 106 million infected patients and patients who died from COVID-19 totalled 2.3 million population (WHO, 2021). Meanwhile, according to data from the Ministry of Health updated on February 19, 2021, the total number of COVID-19 cases in Indonesia reached 1,263. 299 cases with a total of 34,152 cases and 34,152 cases of recovered and dead, respectively (Kementerian Kesehatan, 2021). In South Sulawesi alone, it has reached 53,569 (Dinas Kesehatan Provinsi Sulawesi Selatan, 2021). In this case, the government in various countries around the world, including the Republic of Indonesia, took decisive steps to prevent further spread. At the end of March 2020, the President of Indonesia announced large-scale social restrictions that were useful to minimize the transmission of the corona virus (Setiati and Azwar, 2020), so that this resulted in an increase in the number of poverty rates in Indonesia.

During the current pandemic, as many as 29.12 million people of working age were affected, of which 2.56 million people were unemployed, 1.77 million people did not work temporarily, and as many as 24.03 million people experienced a reduction in working hours (Biro Humas Kemnaker, 2020). Likewise for underemployed workers, whose working time is less than normal working hours (35 hours) has increased, so there are indications that people's income will decrease (Fauzia, 2021).

Infectious diseases are expected to disappear as medical research for vaccines, antibiotics, and quality of life improves in the mid-20th century (Nur et al., 2018), but because it takes time to process, a model is needed to analyse the impact to find solutions of the current problems.

Mathematical models are formed and analyzed, in order to be representative of the problems discussed (Side et al., 2016). Research on mathematical modeling of SEIRS, SIRS on COVID-19 disease transmission has been carried out by (Abdy et al., 2021; Annas et al., 2020; Singhal, 2020; Yang and Wang, 2020), then in typhoid (Nurhaeda et al., 2021); the SEIAS-SEI model of malaria transmission (Maryam et al., 2021); SEIRS model on Rubella (Asri et al., 2021); SEIRI Model in Hepatitis B (Side et al., 2021); SIRS model in dengue fever (Sanusi et al., 2021); but focus on disease transmission. The SEIRS mathematical model for social problems has been carried out by (Anwar et al., 2021) but focusing on the problem of online game addiction, no one has yet modeled on the problem of poverty as a result of the Covid-19 pandemic. Therefore, this study discusses the SAPR mathematical model that can find the best solution in dealing with social problems of poverty in the city of Makassar.

\section{B. LITERATURE REVIEW}

\section{Equilibrium Point of System}

The equilibrium point is a state of a system that does not change with time. If the dynamics system is described in a differential equation, then the equilibrium point is obtained with the first derivative equal to zero (Side et al., 2020). The point $\bar{x} \in R^{n}$ is called the equilibrium point of $\dot{x}=f^{\prime}(x)$ if it satisfies $f^{\prime}(x)=0$, where

$$
f^{\prime}(x)=\left[\begin{array}{c}
f_{1}\left(x_{1}, x_{2}, \ldots, x_{n}\right) \\
f_{2}\left(x_{1}, x_{2}, \ldots, x_{n}\right) \\
\vdots \\
\left.\left.f_{n}\left(x_{1}, x_{2}, \ldots, x_{n}\right)\right)\right)
\end{array}\right]
$$

\section{Equilibrium Point Stability Analysis}

Consider a non-linear PD system of order-n in Equation (2)

$$
x_{i}=A x+f_{i}\left(x_{1}, x_{2}, \ldots, x_{n}\right), i=1,2, \ldots, n
$$

The first step for solving equation (2) is to find the equilibrium point. For example, the equilibrium point of balance $\left(x_{1}^{*}, x_{2}^{*}, \ldots, x_{n}^{*}\right)$, then the next step is to determine the Jacobian matrix. Let $G_{i}\left(x_{1}, x_{2}, \ldots, x_{n}\right)=A x+f_{i}\left(x_{1}, x_{2}, \ldots, x_{n}\right)$, then Jacobian matrix is

$$
A=\left[\begin{array}{ccc}
\frac{\partial G_{1}}{\partial x_{1}} & \cdots & \frac{\partial G_{1}}{\partial x_{n}} \\
\vdots & \ddots & \vdots \\
\frac{\partial G_{n}}{\partial x_{1}} & \cdots & \frac{\partial G_{n}}{\partial x_{n}}
\end{array}\right]
$$


Furthermore, substituting the equilibrium point on the Jacobi matrix and we found a linear system in Equation (4).

$$
\dot{u}_{i}=A_{\left(x_{1}^{*}, x_{2}^{*}, x_{n}^{*}\right)} u
$$

Determination of the stability of the equilibrium point is obtained by finding the value of the real part of the eigenvalue $\lambda_{i}$. In general, the stability of the equilibrium point has two behaviors (Side et al., 2020), namely:

i. Stable if $\operatorname{Re}\left(\lambda_{i}\right)<0, \forall i$ or $\exists R e\left(\lambda_{j}\right)=0, \forall j$ and $\operatorname{Re}\left(\lambda_{i}\right)<0, \forall i \neq j$.

ii. Unstable if there is at least one $i$ such that $\operatorname{Re}\left(\lambda_{i}\right)>0$.

\section{The Basic Reproduction Number}

The basic reproduction number is the number of individuals potentially affected by social poverty caused by the spread of Covid-19. In general, the basic reproduction number $R_{0}$ has three possibilities, namely:

a. if $R_{0}<1$, then the poverty rate of the social population is decreasing.

b. if $R_{0}=1$, then the social population poverty rate constant.

c. if $R_{0}>1$, then the poverty rate of the social population increasing.

\section{RESEARCH METHOD}

This research is a theoretical and applied study, means, reviewing the literature on mathematical modeling and social cases of poverty in Makassar. The mathematical model in this study is the Suspectible, Affective, Poor and Recovered (SAPR) model which was developed from the SEIR model (Annas et al., 2020) and the SIR model (Abdy et al., 2021). The data used in this study is primary data for residents of the Makassar city who were affected by poverty problems after the transmission of Covid-19. The population of this study is the entire community in the Makassar city amounted to 1.508 million people. Due to the large population, it is necessary to draw a research sample. Sampling is done by random sampling, random is done because all classes of the population are homogeneous. So that the number of samples used in the study as many as 400 people from the distribution of all sub-districts in Makassar city is presented in Table 1. The stages of this research are: Building the Susceptible, Affective, Poor and Recovered (SAPR) model on the level of social poverty, determining and analyzing the stability of the equilibrium point, determining the value of the basic reproduction number (R0), conducting model simulations using Maple for social problems of poverty and conclusions.

Table 1. Sample Distribution Data per District in Makassar City

\begin{tabular}{llll}
\hline District & Total & District & Total \\
\hline Mariso & 16 & Bontoala & 15 \\
Mamajang & 17 & Ujung Tanah & 13 \\
Tamalate & 53 & Tallo & 38 \\
Rappocini & 45 & Panakukkang & 40 \\
Makassar & 23 & Manggala & 38 \\
Ujung Pandang & 8 & Biringkanaya & 55 \\
Wajo & 9 & Tamalanrea & 30 \\
\hline
\end{tabular}

\section{RESULT AND DISCUSSION}

\section{SAPR Model for Social Problems of Poverty}

The population in the model is divided into four compartment, namely the Susceptible (S) which states the class of individuals who are potentially socially affected by poverty due to the spread of Covid-19, Affective (A) which states the class of individuals affected by social poverty due to the spread of Covid-19, Poor (P) which states that the individual class has fallen into poverty due to the spread of Covid-19, and the Rise (R) which states that the individual class is not poor.

The assumptions used in the model are: The community resides and is domiciled in Makassar; There are people who are economically affected during the Covid-19 pandemic; There are people who have family responsibilities; People who enter the class potentially affected by the Covid-19 pandemic (Susceptible) are those who have a job (not their own business) or their own business before the Covid-19 pandemic; People who fall into classes affected by the Covid-19 pandemic (Affective) are 
those who have lost their jobs (not their own businesses), have financial problems in their business, increased expenses and reduced income during the Covid-19 pandemic; People who fall into the poverty class (Poor) are those who meet the poverty indicators set by the Central Statistics Agency; People who are included in the free class of poverty (Rise) are people who are free from poverty indicators determined by the Central Statistics Agency; Active independently and creatively in opening a business and creating new jobs; The effectiveness of government assistance in reducing poverty; Assistance, supervision and provision of business capital assistance directly from related parties to help the community to open businesses and create new jobs. The schema of the social poverty SAPR model can be seen in Figure 1, while the definitions of variables and parameters used are presented in Table 2.

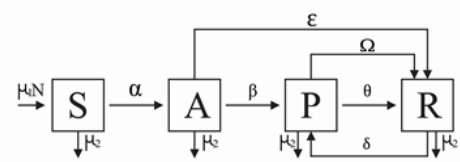

Figure 1. Schematic of The SAPR Model for Poverty Social Problem

Figure 1 can be interpreted into a mathematical model which is a nonlinear differential equation presented in the Equation (5) system.

$$
\begin{aligned}
& \frac{d S}{d t}=\mu_{1} N-\left(\alpha+\mu_{2}\right) S \\
& \frac{d A}{d t}=\lambda S-\left(\beta+\mu_{2}+\varepsilon\right) A \\
& \frac{d P}{d t}=\beta A+\delta R-\left(\theta+\Omega+\mu_{2}\right) P \\
& \frac{d R}{d t}=(\theta+\Omega) P+\varepsilon A-\delta R-\mu_{2} R
\end{aligned}
$$

\begin{tabular}{|c|c|}
\hline $\begin{array}{l}\text { Variable/ } \\
\text { Parameter }\end{array}$ & Definition \\
\hline $\mathrm{S}$ & The total population of Makassar City \\
\hline A & The number of people affected by socio-economic problems after the spread of Covid-19 \\
\hline $\mathrm{P}$ & The number of people who have poor socioeconomic conditions after the spread of Covid-19 \\
\hline $\mathrm{R}$ & The number of people who are free from poor social conditions after the spread of Covid-19 \\
\hline$\mu_{1}$ & The rate of population growth is affected in a special case in the city of Makassar \\
\hline$\mu_{2}$ & The rate of decline and the reduction of the affected population in normal cases in Makassar city \\
\hline$\alpha$ & $\begin{array}{l}\text { The rate of people's movement from a class of people living in Makassar (susceptible) to a class of people } \\
\text { who are affected by socio-economic problems after the spread of Covid-19 (affected) }\end{array}$ \\
\hline$\beta$ & $\begin{array}{l}\text { The rate of people movement from social classes affected by socio-economic problems after the Covid-19 } \\
\text { spread (affected) to people with poor socioeconomic conditions after the spread of Covid-19 (poor) }\end{array}$ \\
\hline$\delta$ & $\begin{array}{l}\text { The rate of movement of people from the social class that has socio-economic conditions that are free of } \\
\text { poverty after Covid-19 spreads (rise) to the class of people who are in poor social conditions after the spread } \\
\text { of Covid-19 (poor) }\end{array}$ \\
\hline$\theta$ & $\begin{array}{l}\text { The rate of movement of people from the social class that has poor socioeconomic conditions after Covid-19 } \\
\text { spread (poor) to a class of people who are free from poor social conditions after the spread of Covid-19 (rise) } \\
\text { and the effectiveness of government programs in increasing business actors in the socio-economic world }\end{array}$ \\
\hline$\varepsilon$ & $\begin{array}{l}\text { The rate of people movement from social classes affected by socio-economic problems after the spread of } \\
\text { Covid-19 (affected) to classes free from poor social conditions after the spread of Covid-19 (rise) }\end{array}$ \\
\hline$\Omega$ & $\begin{array}{l}\text { Assistance, supervision and provision of business capital assistance directly from related parties to help the } \\
\text { community to open businesses and open new jobs }\end{array}$ \\
\hline
\end{tabular}

Where $N=S+A+P+R$ is the total number of population.

Table 2. Definition of Variables and Parameters of SAPR Model 


\section{Model SAPR Analysis for Poverty Social Problem}

\section{a. Equilibrium Point Analysis of SAPR Model}

The equilibrium point in the System of Equations (5) is obtained if $\left(\frac{d S}{d t}, \frac{d A}{d t}, \frac{d P}{d t}, \frac{d R}{d t}\right)=(0,0,0,0)$. The system of equation (5) has two equilibrium points, namely the equilibrium point free from poverty $E_{0}$ and the equilibrium point for poor $E_{\varepsilon}$. The equilibrium point free from poverty is obtained with the assumption that $A=0$ and $P=0$ which means there are no poor people and action solutions. Based on the system of equation (5), the poverty-free equilibrium point is obtained kemiskinan $E_{0}(S, A, P, R)=\left(\frac{\mu_{1} N}{\mu_{2}+\alpha}, 0,0,0\right)$. For the poverty equilibrium point, we get $E_{\varepsilon}(S, A, P, R)=$ $\left(S^{*}, A^{*}, P^{*}, R^{*}\right)$, where:

$S^{*}=\frac{\mu_{1} N}{\mu_{2}+\alpha}, A^{*}=\frac{\alpha \mu_{1} N}{\mu_{2}^{2}+\mu_{2} \alpha+\mu_{2} \beta+\mu_{2} \varepsilon+\alpha \delta+\alpha \varepsilon}$,

$P^{*}=\frac{\mu_{1} \alpha\left(\mu_{2} \beta+\beta \delta+\delta \varepsilon\right)}{\mu_{2}\left(\mu_{2}^{3}+\mu_{2}^{2} \Omega+\mu_{2}^{2} \beta+\mu_{2}^{2} \delta+\mu_{2}^{2} \varepsilon+\mu_{2}^{2} \theta+\mu_{2} \Omega(\alpha+\beta+\varepsilon)+\mu_{2} \alpha(\beta+\delta+\varepsilon+\theta)+\mu_{2} \beta(\delta+\theta)+\mu_{2} \delta \varepsilon+\mu_{2} \varepsilon \theta+\Omega \alpha(\beta+\varepsilon)+\alpha \beta(\delta+\theta)+\alpha \varepsilon(\delta+\theta)\right)}$,

$R^{*}=\left(\alpha \mu_{1}\left(\mu_{2} \varepsilon+\Omega \beta+\Omega \varepsilon+\beta \theta+\varepsilon \theta\right)\right) /\left(\mu_{2}\left(\mu_{2}^{3}+\mu_{2}^{2} \Omega+\mu_{2}^{2} \alpha+\mu_{2}^{2} \beta+\mu_{2}^{2} \delta+\mu_{2}^{2} \varepsilon+\mu_{2}^{2} \theta+\mu_{2} \Omega \alpha+\mu_{2} \Omega \beta+\mu_{2} \Omega \varepsilon+\right.\right.$ $\left.\left.\mu_{2} \alpha \beta+\mu_{2} \alpha \delta+\mu_{2} \alpha \varepsilon+\mu_{2} \alpha \theta+\mu_{2} \beta \delta+\mu_{2} \beta \theta+\mu_{2} \delta \varepsilon+\mu_{2} \varepsilon \theta+\Omega \alpha \beta+\Omega \alpha \varepsilon+\alpha \beta \delta+\alpha \beta \theta+\alpha \delta \varepsilon+\alpha \varepsilon \theta\right)\right)$

b. The Jacobian Matrix of SAPR Model

Let given a system of equations (5) and defined in Equation (6)

$$
\dot{x}=f(x), x \in R^{4}
$$

Where $x \in R^{4}$ are the variables contained in equation (6). The Jacobian matrix of Equation (6) is defined in Equation (7).

$$
J=\left[\begin{array}{llll}
\frac{\partial f_{1}}{\partial S} & \frac{\partial f_{1}}{\partial E} & \frac{\partial f_{1}}{\partial I} & \frac{\partial f_{1}}{\partial R} \\
\frac{\partial f_{2}}{\partial S} & \frac{\partial f_{2}}{\partial E} & \frac{\partial f_{2}}{\partial I} & \frac{\partial f_{2}}{\partial R} \\
\frac{\partial f_{3}}{\partial S} & \frac{\partial f_{3}}{\partial E} & \frac{\partial f_{3}}{\partial I} & \frac{\partial f_{3}}{\partial R} \\
\frac{\partial f_{4}}{\partial S} & \frac{\partial f_{4}}{\partial E} & \frac{\partial f_{4}}{\partial I} & \frac{\partial f_{4}}{\partial R}
\end{array}\right]=\left[\begin{array}{cccc}
-\alpha-\mu_{2} & 0 & 0 & 0 \\
\alpha & -\beta-\varepsilon-\mu_{2} & 0 & 0 \\
0 & \beta & -\theta-\Omega-\mu_{2} & \delta \\
0 & 0 & \theta+\Omega & -\delta-\mu_{2}
\end{array}\right]
$$

c. Stability analysis at the Poor-Free Equilibrium Point of SAPR Model

The type of stability of the equilibrium point free from poverty $E_{0}(S, A, P, R)=\left(\frac{\mu_{1} N}{\mu_{2}+\alpha}, 0,0,0\right)$ is obtained by linearizing the system of Equation (7) at $E_{0}$, and obtained the Jacobian matrix in Equation (8).

$$
J E_{0}=\left[\begin{array}{cccc}
-\alpha-\mu_{2} & 0 & 0 & 0 \\
\alpha & -\beta-\varepsilon-\mu_{2} & 0 & 0 \\
0 & \beta & -\theta-\Omega-\mu_{2} & \delta \\
0 & 0 & \theta+\Omega & -\delta-\mu_{2}
\end{array}\right]
$$

Furthermore, with the formula $\operatorname{det}\left(J E_{0}-\lambda I\right)=0$ is obtained the eigenvalue of the Jacobian matrix $J E_{0}$, where $I$ is the identity matrix and the results are presented in Equation (9)

$$
\begin{aligned}
& \operatorname{det}\left(\left[\begin{array}{cccc}
-\alpha-\mu_{2} & 0 & 0 & 0 \\
\alpha & -\beta-\varepsilon-\mu_{2} & 0 & 0 \\
0 & \beta & -\theta-\Omega-\mu_{2} & \delta \\
0 & 0 & \theta+\Omega & -\delta-\mu_{2}
\end{array}\right]-\lambda\left[\begin{array}{cccc}
1 & 0 & 0 & 0 \\
0 & 1 & 0 & 0 \\
0 & 0 & 1 & 0 \\
0 & 0 & 0 & 1
\end{array}\right]\right)=0 \\
& \left|\left[\begin{array}{cccc}
-\alpha-\mu_{2}-\lambda & 0 & 0 & 0 \\
\alpha & -\beta-\varepsilon-\mu_{2}-\lambda & 0 & 0 \\
0 & \beta & -\theta-\Omega-\mu_{2}-\lambda & \delta \\
0 & 0 & \theta+\Omega & -\delta-\mu_{2}-\lambda
\end{array}\right]\right|=0
\end{aligned}
$$

Eigen values of Equation (9) are: $\lambda_{1}=-\alpha-\mu_{2} ; \lambda_{2}=-\beta-\varepsilon-\mu_{2} ; \lambda_{3}=-\theta-\Omega-\mu_{2} ;$ and $\lambda_{4}=-\delta-\mu_{2}$.

Because all of the real eigen values are negative $\left(\lambda_{i}<0, \forall i=1,2,3,4\right)$, then the equilibrium point for a society free from poverty $E_{0}$ is stable. 
d. Stabilty analysis at the Poor Equilibrium Point of SAPR Model

The values of the poor equilibrium points $E_{\varepsilon}(S, A, P, R)$ are:

$S^{*}=\frac{\mu_{1} N}{\mu_{2}+\alpha}, A^{*}=\frac{\alpha \mu_{1} N}{\mu_{2}^{2}+\mu_{2} \alpha+\mu_{2} \beta+\mu_{2} \varepsilon+\alpha \delta+\alpha \varepsilon}$,

$P^{*}=\frac{\mu_{1} \alpha\left(\mu_{2} \beta+\beta \delta+\delta \varepsilon\right)}{\mu_{2}\left(\mu_{2}^{3}+\mu_{2}^{2} \Omega+\mu_{2}^{2} \beta+\mu_{2}^{2} \delta+\mu_{2}^{2} \varepsilon+\mu_{2}^{2} \theta+\mu_{2} \Omega(\alpha+\beta+\varepsilon)+\mu_{2} \alpha(\beta+\delta+\varepsilon+\theta)+\mu_{2} \beta(\delta+\theta)+\mu_{2} \delta \varepsilon+\mu_{2} \varepsilon \theta+\Omega \alpha(\beta+\varepsilon)+\alpha \beta(\delta+\theta)+\alpha \varepsilon(\delta+\theta)\right)}$,

$R^{*}=\left(\alpha \mu_{1}\left(\mu_{2} \varepsilon+\Omega \beta+\Omega \varepsilon+\beta \theta+\varepsilon \theta\right)\right) /\left(\mu_{2}\left(\mu_{2}^{3}+\mu_{2}^{2} \Omega+\mu_{2}^{2} \alpha+\mu_{2}^{2} \beta+\mu_{2}^{2} \delta+\mu_{2}^{2} \varepsilon+\mu_{2}^{2} \theta+\mu_{2} \Omega \alpha+\mu_{2} \Omega \beta+\mu_{2} \Omega \varepsilon+\right.\right.$ $\left.\left.\mu_{2} \alpha \beta+\mu_{2} \alpha \delta+\mu_{2} \alpha \varepsilon+\mu_{2} \alpha \theta+\mu_{2} \beta \delta+\mu_{2} \beta \theta+\mu_{2} \delta \varepsilon+\mu_{2} \varepsilon \theta+\Omega \alpha \beta+\Omega \alpha \varepsilon+\alpha \beta \delta+\alpha \beta \theta+\alpha \delta \varepsilon+\alpha \varepsilon \theta\right)\right)$.

The Jacobian matrix is obtained by linearizing the system of Equation (5) around $E_{\varepsilon}$ and presented in Equation (10).

$$
J E_{0}=\left[\begin{array}{cccc}
-\alpha-\mu_{2} & 0 & 0 & 0 \\
\alpha & -\beta-\varepsilon-\mu_{2} & 0 & 0 \\
0 & \beta & -\gamma-\theta-\Omega-\mu_{2} & 0 \\
0 & 0 & \gamma+\theta+\Omega & -\mu_{2}
\end{array}\right]
$$

Furthermore, with the formula $\operatorname{det}\left(J E_{0}-\lambda I\right)=0$ is obtained the eigenvalue of the Jacobian matrix $J E_{0}$, where I is the identity matrix and the results are presented in Equation (11).

$$
\begin{aligned}
& \operatorname{det}\left(\left[\begin{array}{cccc}
-\alpha-\mu_{2} & 0 & 0 & 0 \\
\alpha & -\beta-\varepsilon-\mu_{2} & 0 & 0 \\
0 & \beta & -\theta-\Omega-\mu_{2} & \delta \\
0 & 0 & \theta+\Omega & -\delta-\mu_{2}
\end{array}\right]-\lambda\left[\begin{array}{cccc}
1 & 0 & 0 & 0 \\
0 & 1 & 0 & 0 \\
0 & 0 & 1 & 0 \\
0 & 0 & 0 & 1
\end{array}\right]\right)=0 \\
& \left|\left[\begin{array}{cccc}
-\alpha-\mu_{2}-\lambda & 0 & 0 & 0 \\
\alpha & -\beta-\varepsilon-\mu_{2}-\lambda & 0 & 0 \\
0 & \beta & -\theta-\Omega-\mu_{2}-\lambda & \delta \\
0 & 0 & \theta+\Omega & -\delta-\mu_{2}-\lambda
\end{array}\right]\right|=0
\end{aligned}
$$

Eigen values of Equation (11) are: $\lambda_{1}=-\alpha-\mu_{2} ; \lambda_{2}=-\beta-\varepsilon-\mu_{2} ; \lambda_{3}=-\theta-\Omega-\mu_{2} ;$ and $\lambda_{4}=-\delta-\mu_{2}$.

Because all of the real eigen values are negative $\left(\lambda_{i}<0, \forall i=1,2,3,4\right)$, then the equilibrium point for a society free from poverty $E_{\varepsilon}$ is stable.

e. The Basic Reproduction Number $\left(R_{0}\right)$

The basic reproduction number of the SAPR model in the Equation (5) system is determined using the next generation matrix method. The class of people to be poverty is Poor $(\mathrm{P})$ so the differential equation used is:

$$
\frac{d I}{d t}=(\beta+\varepsilon) A-\left(\theta+\Omega+\mu_{2}\right) P
$$

Let $\varphi=(\beta+\varepsilon) A$ and $\psi=\left(\theta+\Omega+\mu_{2}\right) P . \varphi$ and $\psi$ linearized, we get Equation (13).

$$
F=(\beta+\varepsilon) ; V=\left(\mu_{2}+\Omega+\theta\right) ; V^{-1}=\frac{1}{\mu_{2}+\Omega+\theta}
$$

Next generation matrix obtained from the multiplication $\mathrm{F}$ and $V^{-1}$ which is presented in Equation (14)

$$
F=(\beta+\varepsilon) ; V=\left(\mu_{2}+\Omega+\theta\right) ; K=F V^{-1}=\beta+\varepsilon \frac{1}{\theta+\Omega+\mu_{2}}
$$

So that the basic reproduction number is obtained in Equation (15).

$$
R_{0}=\frac{\beta+\varepsilon}{\theta+\Omega+\mu_{2}}
$$

\section{SAPR Model Simulation for Poverty Social Problem}

The simulation of the SAPR model for social problems of poverty in Makassar City using Maple. Initial values of variables and parameters are presented in Table 3. While the results of model simulations are presented in Figure 2 to Figure 5. The 
simulation of the SAPR model on the population rate of social poverty cases with solutions and without solutions and with the consideration that the population growth rate is the same as the population decline rate and the rate of population decline. Growth is twice the rate of population decline. The simulation of the SAPR model for the social problem of poverty without a solution with the same rate of population growth and decline in Makassar City is presented in Figure 2; The simulation of the SAPR model for the social problem of poverty without a solution with a predicted rate of increasing that is twice as large as the rate of population decline in the Makassar city area is presented in Figure 3; The simulation of the SAPR model for the social population rate of poverty without a solution with an increasing rate that is twice as large as the rate of population decline in the Makassar city area is presented in Figure 4; and the simulation of the SAPR model population rate of social solutions to poverty with the rate of increasing and decrease in population in the Makassar city area is presented in Figure 5.

Table 3. The Value of The Parameters of The SAPR Model for The Social Problem of Poverty

\begin{tabular}{cccc}
\hline Variable & Value & Parameter & Value \\
\hline $\mathrm{S}(0)$ & 100 & $\alpha$ & 0,25 \\
$\mathrm{~A}(0)$ & 90 & $\beta$ & 0,525 \\
$\mathrm{P}(0)$ & 176 & $\delta$ & 0,25 \\
$\mathrm{R}(0)$ & 34 & $\varepsilon$ & 0,0125 \\
$\mathrm{~N}$ & 400 & $\theta$ & 0,16 \\
\hline
\end{tabular}

Using the parameter values in Table 2 , the basic reproduction number $R_{0}=2.067$ is obtained. $\left.R_{(} 0\right)>1$ indicates that the social poverty population rate in Makassar City will continue to increasing, so the role of the Makassar City Government is needed.

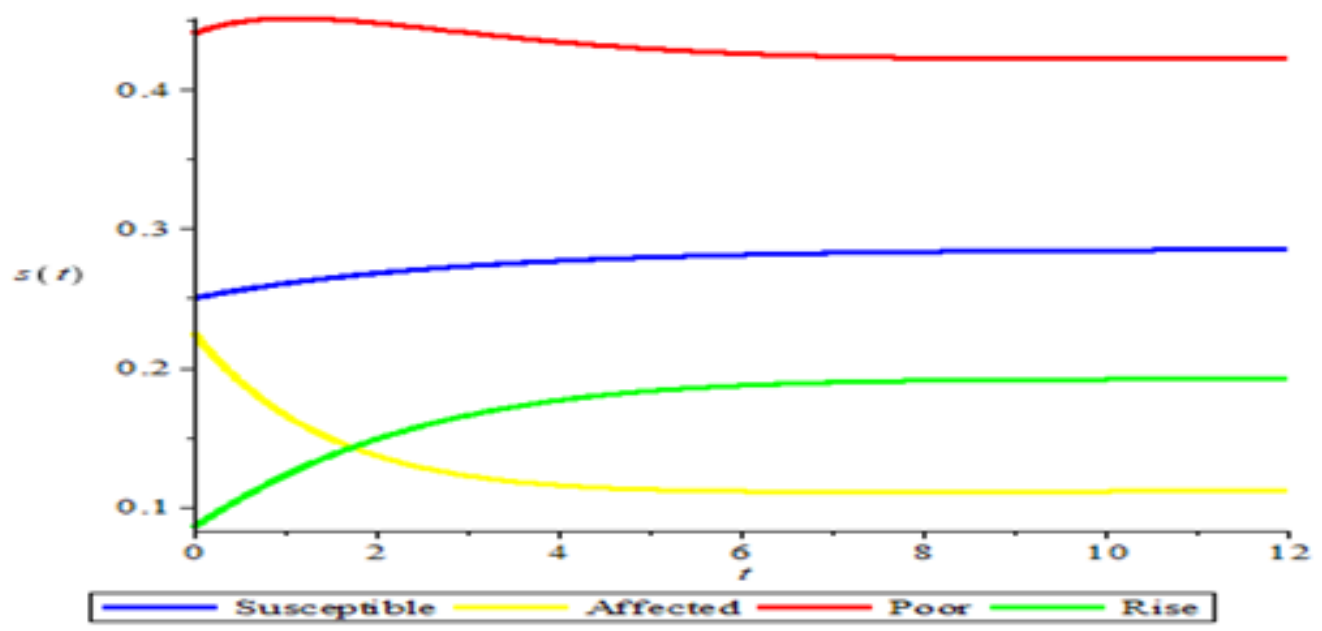

Figure 2. Prediction of The Population Rate on The Social Problem of Poverty without A Solution with The Increasing and Decreasing in The Same Population in Makassar City

Figure 2 shown that for the social problem of poverty without a solution in Makassar City with the increasing and decreasing in the number of people being the same, the predicted number of samples has the potential to increasing from the initial value of 100 people to 120 people for 12 months. The number of affected samples decreasing from the initial value of 90 people to 40 people for 12 months. The number of samples who fell into poverty increasing and decreasing for 12 months from the initial value of 176 people to 160 to 180 people. The number of samples that managed to rise from poverty has increasing from 34 people to 80 people for 12 months. 


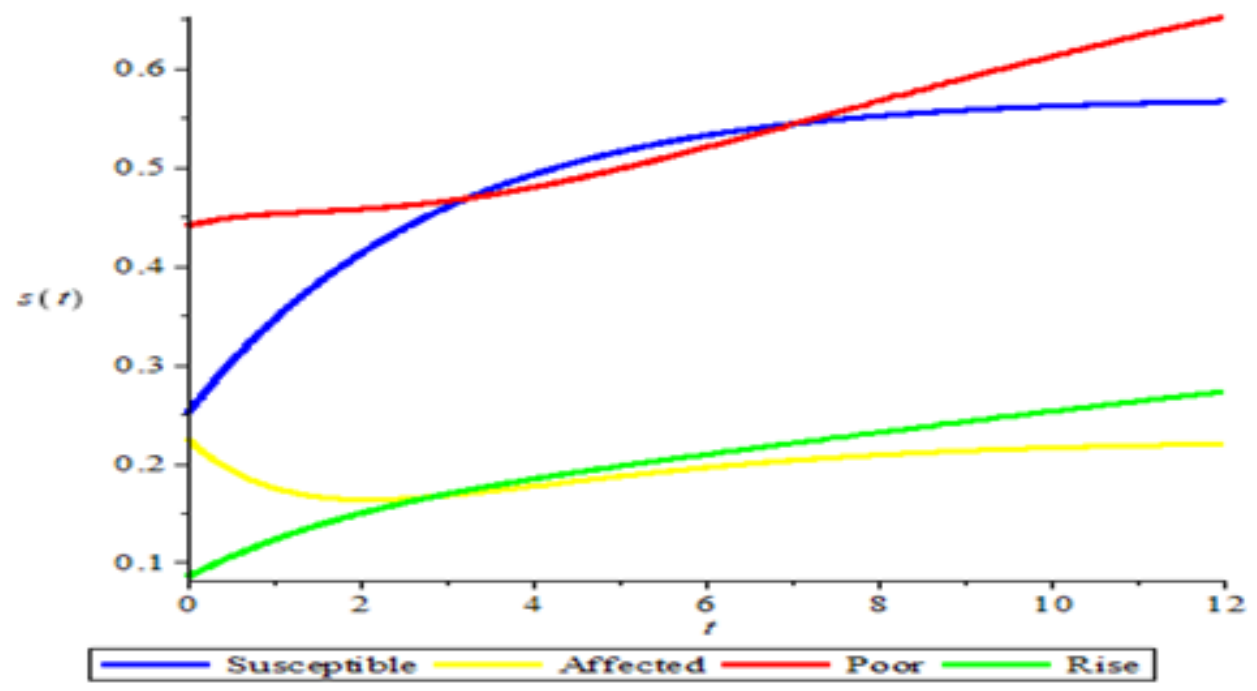

Figure 3. Prediction of The SAPR Model for The Social Problem of Poverty without A Solution with A Population Growth Rate That is Twice as Large as The Population Decline in The City of Makassar

Figure 3 shown that in the social problem of poverty without a solution in Makassar City with a population growth rate that is twice as large as the decline in population, the predicted number of samples has the potential to increasing from the initial value of 100 people to 240 people for 12 months. The number of affected samples decreasing from the initial value of 90 people to 60 people for 12 months. The number of samples who fell into poverty increasing from the initial value of 176 people to 280 people for 12 months. The number of samples that managed to rise from poverty has increasing from the observation of 34 people to 136 to 160 people for 12 months.

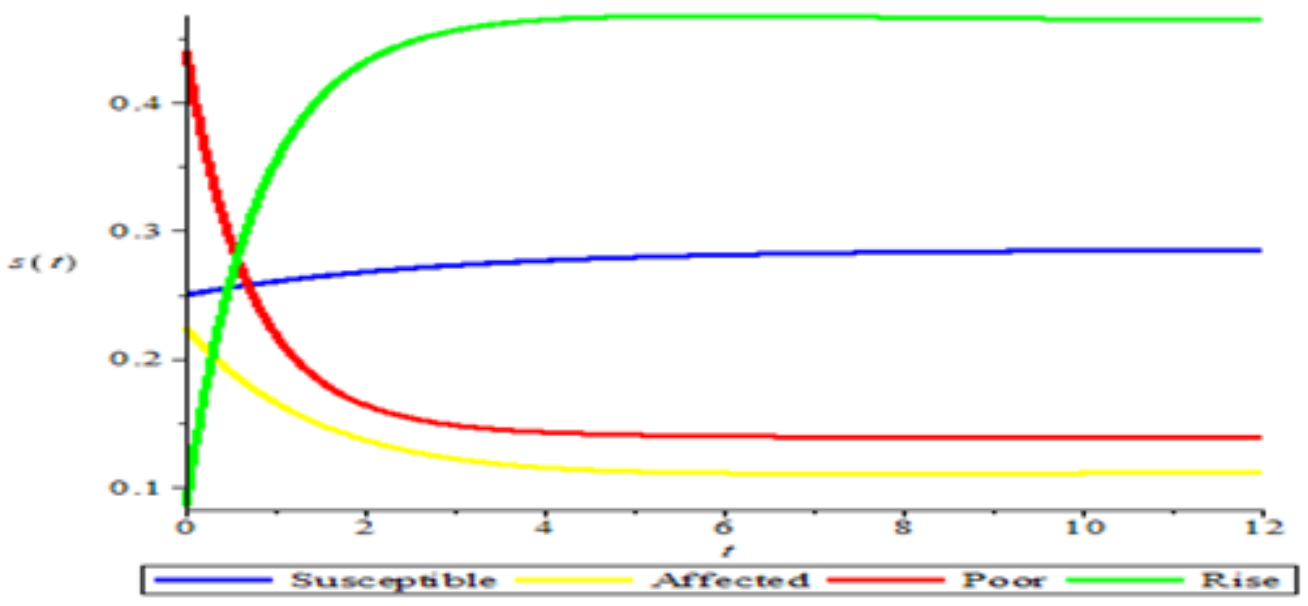

Figure 4. Prediction of The SAPR Model for The Social Problem of Poverty with Solutions and

The Same Increasing and Decreasing in The Number of Residents in Makassar City

Figure 4 shown that in the social problem of poverty with solutions in Makassar City and the increasing and decreasing in the number of residents are the same, the predicted number of samples has the potential to increase from the initial value of 100 people to 120 people over 12 months. The number of affected samples decreasing from the initial value of 90 people to 40 people for 12 months. The number of samples who fell into poverty decreasing from the initial value of 176 people to less than 60 people for 12 months. The number of samples that managed to rise from poverty increasing from 34 people to 200 people for 12 months. 


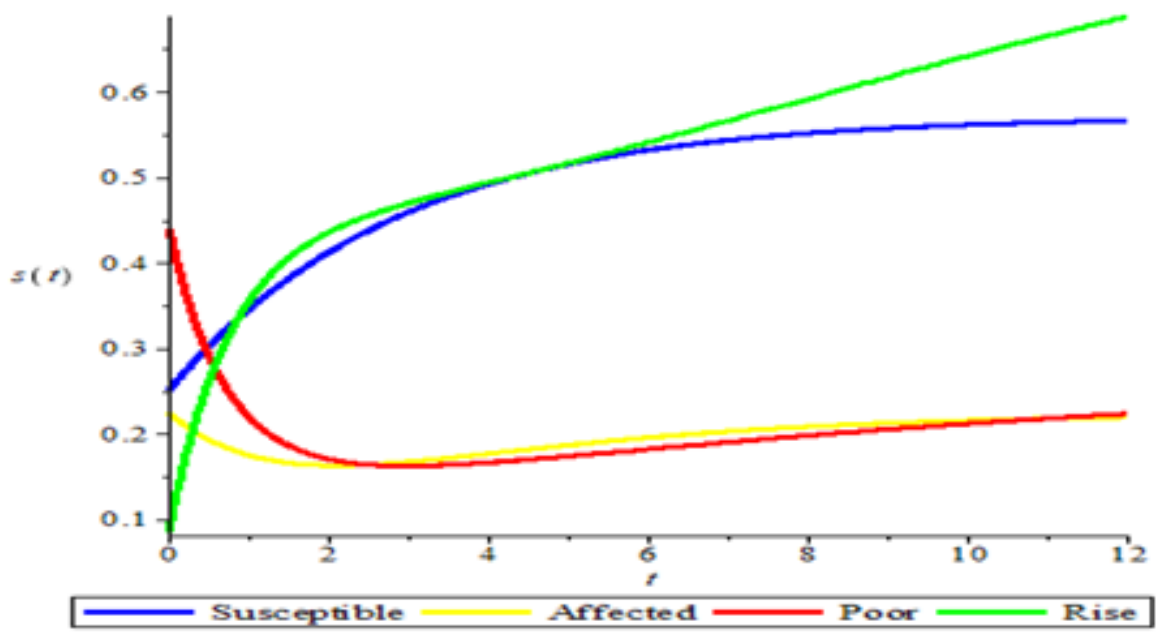

Figure 5. Prediction of The SAPR Model for The Social Problem of Poverty with Solutions and A Population Growth Rate That is Twice as Large as The Population Decline in The City of Makassar

Figure 5 shown that in the social problem of poverty with solutions in Makassar City and the rate of population growth is twice as large as the decline in population, the predicted number of samples has the potential to increase from the initial value of 100 people to 240 people over 12 months. The number of affected samples decreased from the initial value of 90 people to 60 people for 12 months. The number of samples who fell into poverty decreased from the initial value of 176 people to 80 people for 12 months. The number of samples that managed to rise from poverty increased from 34 people to 280 people for 12 months.

Based on Figure 4 and Figure 5, it is found that the decline in social poverty cases has occurred in the last 6 months, so it is concluded that the role of the government in helping and developing small and medium enterprises to the poor as a result of Covid-19 will greatly help the people of Makassar city to suppress the increase in cases. social poverty, so that Makassar City becomes a poor free city can be realized in the future.

Research results (Annas et al., 2020) of the SEIR model for the spread of Covid-19 were able to predict an increase in the number of Covid-19 cases in Indonesia, the model became the basis for the formation of the SAPR model for social problems of poverty in the city of Makassar. Research results (Ristyaningrum, 2020) shown that there is a lack of government role in helping SMEs, or only following up on the rules of Law 9/1995 on Small Business and Law 20/2008 on SMEs by providing business assistance without further control, while the results of this study shows that the number of people who fall into poverty under normal circumstances increases $+1 \%$ every year.

According to the head of the Makassar Social Service during the Covid-19 pandemic, the poverty rate in Makassar reached 154,632 families, based on integrated social welfare data, there were 82,326 households prior to the Covid-19 pandemic. 19 or an addition of around 72,306 poor families in Makassar or +2 times (Ristyaningrum, 2020). In line with this, the results of this research simulation shown that the number of families who fall into poverty reaches $+70 \%$ of the total families in Makassar City over the next 12 months. For these two cases, the basic reproduction number without control is $R_{0}=2.067>1$, this means that the rate of social poverty cases in Makassar City is in a state that can no longer be tolerated and the Government's role is needed in controlling and resolving cases of poverty problems in Makassar City. While the simulation results after giving control, obtained a decrease in the basic reproduction number $R_{0}=0.426<1$. This shown that the provision of control in the form of the government's role is not limited to providing business assistance but also providing guidance and supervision can help reduce the rate of increasing in social poverty cases in the city of Makassar.

\section{E. CONCLUSION AND SUGGESTION}

Based on the results and discussion, the conclusions of this study are: The SAPR mathematical model can be a solution in solving social problems of poverty in general; The analysis of the SAPR model shown that the social poverty level of the population produces two equilibrium points, namely the free equilibrium point of the poor and the poor equilibrium point, both of which are stable; The model simulation results shown that the government has an important role in increasing the number of poor people in 
Makassar City, especially during the pandemic Covid-19; The solution to the problem of the social poverty level of the population using the SAPR model can be a recommendation for the Government in an effort to reduce the number of poor people in Makassar City.

\section{ACKNOWLEDGEMENT}

We would like thanks to Kemendikbudristek for financial support. Also thanks to Universitas Negeri Makassar and Makassar community for supporting data this research.

\section{REFERENCES}

Abdy, M., Side, S., Annas, S., Nur, W., and Sanusi, W. (2021). An SIR Epidemic Model for COVID-19 Spread with Fuzzy Parameter: The Case of Indonesia. Advances in Difference Equations, 2021(1).

Annas, S., Isbar Pratama, M., Rifandi, M., Sanusi, W., and Side, S. (2020). Stability Analysis and Numerical Simulation of SEIR Model for Pandemic COVID-19 Spread in Indonesia. Chaos, Solitons and Fractals, 139:110072.

Anwar, A., Syam, R., Pratama, M. I., and Side, S. (2021). SEIRS Model Analysis for Online Game Addiction Problem of Mathematics Students. Journal of Physics: Conference Series, 1918(4).

Asri, M., Sidjara, S., Sanusi, W., and Side, S. (2021). Analysis and Solution of The SEIRS Model for The Rubella Transmission with Vaccination Effect Using Runge-Kutta Method. Journal of Physics: Conference Series 1899(2021)012090.

Biro Humas Kemnaker (2020). Menaker Ida: 29.12 Juta Orang Penduduk Usia Kerja Terdampak Pandemi Covid-19. https: //kemnaker.go.id/News/Detail/Menaker-Ida-2912-Juta-Orang-Penduduk-Usia-Kerja-Terdampak-Pandemi-Covid-19.

Dinas Kesehatan Provinsi Sulawesi Selatan (2021). Sulsel Tanggap Covid-19.

Fauzia, M. (2021). Penduduk Miskin Indonesia Naik Jadi 27.55 Juta Akibat Covid-19, Tren Penurunan Kemiskinan Terhenti. https://money.kompas.com/Read/2021/02/16/073400926/ Penduduk-Miskin-Indonesia-Naik-Jadi-27-55-Juta-Akibat-Covid-19-Tren-Penurunan?Page=All.

Kementerian Kesehatan, R. I. (2021). COVID 19 di Indonesia.

Maryam, H., Abdy, M., Alimuddin, and Side, S. (2021). SEIAS-SEI Model on Asymptomatic and Super Infection Malaria with Imperfect Vaccination. Journal of Physics: Conference Series, 1918(4).

Nur, W., Rachman, H., Abdal, N. M., Abdy, M., and Side, S. (2018). SIR Model Analysis for Transmission of Dengue Fever Disease with Climate Factors Using Lyapunov Function. Journal of Physics: Conference Series, 1028(1).

Nurhaeda, Anas, S., and Side, S. (2021). Analysis and Simulation of Mathematical Model for Typhus Disease in Makassar. Journal of Physics: Conference Series, 1918(4):0-6.

Ristyaningrum, A. (2020). Kemiskinan di Makassar Meningkat Signifikan. https://sulawesi.bisnis.com/read/20200519/539/ 1242746/kemiskinan-di-makassar-meningkat-signifikan.

Sanusi, W., Pratama, M. I., Rifandi, M., Sidjara, S., Irwan, and Side, S. (2021). Numerical Solution of SIRS Model for Dengue Fever Transmission in Makassar Citywith Runge Kutta Method. Journal of Physics: Conference Series, 1752(1).

Sauddin, A., Alwi, W., and AN, A. N. (2019). Klasifikasi Tingkat Partisipasi Angkatan Kerja Kota Makassar Menggunakan Metode CART Adnan Sauddin. Jurnal MSA, 7(2):20-36.

Setiati, S. and Azwar, M. K. (2020). COVID-19 and Indonesia. 51(1):84-89.

Shereen, M. A., Khan, S., Kazmi, A., Bashir, N., and Siddique, R. (2020). COVID-19 Infection: Origin, Transmission, and Characteristics of Human Coronaviruses. Journal of Advanced Research, 24:91-98. 
Side, S., Abdy, M., Arwadi, F., and Sanusi, W. (2021). SEIRI Model Analysis Using The Mathematical Graph as a Solution for Hepatitis B Disease in Makassar. Journal of Physics: Conference Series, 1899(1).

Side, S., Muzakkir, N., Pebriani, D., and Utari, S. (2020). Model SEIR Kecanduan Game Online pada Siswa di SMP Negeri 3 Makassar. Jurnal Sainsmat, 9(1):91-102.

Side, S., Sanusi, W., Aidid, M. K., and Sidjara, S. (2016). Global Stability of SIR and SEIR Model for Tuberculosis Disease Transmission with Lyapunov Function Method. Asian Journal of Applied Sciences, 9(3):86-96.

Singhal, T. (2020). Review on COVID19 Disease So Far. The Indian Journal of Pediatrics, 87(April):281-286.

Torrealba-Rodriguez, O., Conde-Gutiérrez, R. A., and Hernández-Javier, A. L. (2020). Modeling and Prediction of COVID-19 in Mexico Applying Mathematical and Computational Models. Chaos, Solitons and Fractals, 138.

WHO (2021). COVID-19 Coronavirus Pandemic.

Yang, C. and Wang, J. (2020). A Mathematical Model for The Novel Coronavirus Epidemic in Wuhan, China. HHS Public Access, 17(3):2708-2724. 
